\title{
Necrotizing fasciitis resulting from human bites: A report of two cases of disease caused by group A streptococcus
}

\author{
Christopher A Sikora MSc MD ${ }^{1}$, Jack Spielman MD FRCSC ${ }^{2}$, Kerry MacDonald MD FRCPC ${ }^{3}$, \\ Gregory J Tyrrell PhD FCCM ${ }^{4}$, John M Embil MD FRCPC 5
}

CA Sikora, J Spielman, K MacDonald, GJ Tyrrell, JM Embil. Necrotizing fasciitis resulting from human bites: A report of two cases of disease caused by group A streptococcus. Can J Infect Dis Med Microbiol 2005;16(4):221-224.

Necrotizing fasciitis is a serious and potentially life-threatening condition. Although bite wounds are common, they are not frequently reported as a cause of necrotizing fasciitis. In the present article, two cases of bite-associated necrotizing fasciitis caused by group A streptococcus are reported. Previously published cases are also reviewed.

\section{Deux cas de fasciite nécrosante causée par des streptocoques du groupe A par suite de mor- sures humaines}

Key Words: Bite wound; Bites; Necrotizing fasciitis; Streptococcus pyogenes

$\mathrm{N}$ Tecrotizing fasciitis (NF) is a process involving the subcutaneous tissues, and may spread rapidly to involve neighboring tissues (1). NF can be divided into two types. Type $1 \mathrm{NF}$ is a polymicrobial variant from which Gram-positive, Gramnegative and anaerobic bacteria are recovered, whereas type 2 NF is caused most frequently by group A streptococcus (GAS). However, other streptococci, such as those from groups $\mathrm{C}, \mathrm{G}$ and B, may also be responsible for this condition (2). Type 1 NF occurs most frequently from abdominal and perineal surgeries, while type 2 NF has been associated with minor injuries and breaks in the skin, such as in episodes of varicella (3). NF is uncommon, accounting for $5 \%$ to $12 \%$ of invasive GAS disease; however, NF is associated with significant fear and panic due to the attention it garners from the media. Clinically, it may be difficult to differentiate necrotizing infections from more common skin and soft tissue processes such as cellulitis. Common clinical practice suggests that NF should be strongly considered in the differential diagnosis if there is pain out of proportion to the clinical manifestations (4). NF is thought to be mediated by a number of streptococcal extracellular products, including various DNases, hyaluronidase, streptokinase and streptococcal pyrogenic exotoxin B. In addition, various superantigen toxins may also play a role in NF, eventually leading to massive cytokine release and tissue injury (5-7).
Prompt diagnosis, early intervention with antibiotics and surgical debridement is necessary to reduce the severity of the disease. In cases of streptococcal toxic shock syndrome (STSS), immunoglobulin therapy has been used with some success $(8,9)$. Clinically, although NF may initially appear benign, there is undermining of the tissues beneath the skin, as well as severe pain; therefore, a high index of suspicion is necessary for early detection (4).

For epidemiological purposes, NF has been previously classified histopathologically by the presence of necrosis of superficial fascia and polymorphonuclear cell infiltrates with edema of the dermas subcutaneous fat and superficial fascia. If specimens are unavailable for histopathological analysis, the diagnosis can be made with the presence of gross fascial edema and necrosis of the superficial fascia detected at the time of surgery (10).

Although human bite injuries are common, there have been few reported cases of NF or STSS related to bites (11-15). In the present paper, we describe two cases of patients that developed NF from human bites as a result of GAS. Both cases were managed in a secondary care setting with limited diagnostic capabilities. These patients were assessed and clinically managed with treatment consisting of broad-spectrum antibiotics and surgical debridement before the resolution of the process. Wound cultures from both patients yielded GAS;

${ }^{1}$ Department of Community Medicine, University of Alberta, Edmonton, Alberta; ${ }^{2}$ Department of General Surgery and ${ }^{3}$ Department of Pathology, Lake of the Woods District Hospital, Kenora, Ontario; ${ }^{4}$ National Centre for Streptococcus, Provincial Laboratory of Alberta, Edmonton,

Alberta; ${ }^{5}$ Section of Infectious Diseases, Department of Medicine, University of Manitoba, Winnipeg, Manitoba

Correspondence: Dr John M Embil, Infection Prevention and Control Unit, Health Sciences Centre, MS 673-820 Sherbrook Street, Winnipeg,

Manitoba R3A 1R9. Telephone 204-787-4654, fax 204-787-4699, e-mail jembil@hsc.mb.ca

Received for publication July 26, 2004. Accepted January 10, 2005 
however, pulsed-field gel electrophoresis and $\mathrm{M}$ typing data indicated that the two strains of GAS were unrelated.

\section{CASE PRESENTATIONS}

\section{Case 1}

A 19-year-old man without known previous medical problems presented to the emergency department of the Lake of the Woods District Hospital (Kenora, Ontario) with a three-day history of generalized malaise and progressive pain and edema of his penis after having received fellatio from his female partner. He recalled that during the oral sex, his girlfriend's teeth had nicked his foreskin. At the time of presentation, he had an oral temperature of $38.7^{\circ} \mathrm{C}$, a heart rate of 140 beats $/ \mathrm{min}$ and a blood pressure of 108/60 $\mathrm{mmHg}$ in his right arm (read from a sitting position). Physical examination revealed that his uncircumcised penis was markedly edematous and purpuric, had signs of gangrene of the foreskin, and was very painful to palpation. Purulent discharge was absent from the urethra. The scrotum, anus and rectum were all clinically unremarkable, and pain was absent on palpation. The abdomen was benign. His leukocyte count at the time of admission was $19.4 \times 10^{9} / \mathrm{L}$, and the rest of his complete blood count was unremarkable. His serum electrolytes and coagulation parameters were within normal limits.

Although the presumptive diagnosis was NF, Fournier's gangrene was also entertained in the differential diagnosis, and the patient was urgently taken to the operating theatre for surgical exploration of the affected area. An incision along the dorsal surface of the penis revealed that the penis was edematous, filled with seropurulent fluid separating the deep penile fascia from overlying layers of tissue. Involvement of the superficial and investing fascia was observed. The incision was extended to the symphysis pubis, and all of the undermined skin was debrided of necrotic superficial penile fascia and necrotic penile skin. A Gram stain of the superficial penile fascia and surrounding seropurulent fluid revealed Gram-positive cocci in chains and pairs. Ampicillin and clindamycin were initiated preoperatively and, after discussion with a consultant in infectious diseases, gentamicin was added in the immediate postoperative period. These agents were selected to provide antimicrobial activity in the event that this process represented GAS NF or Fournier's gangrene. GAS was ultimately the only microorganism recovered from all of the submitted specimens. Histology of the submitted tissue showed florid, suppurative inflammation and necrosis of the deeper tissue, as well as intact overlying skin, indications that were compatible with the diagnosis of NF. On the following day, the patient returned to the operating theatre for a second examination and underwent further debridement of all remaining penile skin, which had become necrotic. Oropharyngeal swabs for the detection of GAS from his partner were not obtained. His partner did, however, receive postexposure prophylaxis with cephalexin $500 \mathrm{mg}$ by mouth four times a day for 14 days as part of local public health policy for suspected GAS carriers.

The patient underwent skin grafting and successful reconstruction of his penis, which was initially complicated by contracture of the skin graft; however, the patient noted one year later that he fully recovered his sexual and urological functions.

The strain of GAS that caused this patient's NF was typed as M77, $\mathrm{T}$ type $13 / 28, \mathrm{R}$ type 28 , antiopacity factor 77 , and serum opacity factor-positive.

\section{Case 2}

A previously healthy 18 -year-old woman presented to the emergency department of the Lake of the Woods District Hospital with a two-day history of progressive pain in her left thigh. One day before the onset of her left thigh discomfort, the patient and her mother had an altercation that involved her mother biting her left thigh. At the time of presentation, the patient had an oral temperature of $37.5^{\circ} \mathrm{C}$, a blood pressure of 136/80 $\mathrm{mmHg}$ and a heart rate of 106 beats/min. Her left thigh was erythematous and grossly edematous. In the centre of the erythematous area was a grossly infected human bite with a necrotic central area of $1 \mathrm{~cm}$ in diameter. At the time of admission, she had a leukocyte count of $15.5 \times 10^{9} / \mathrm{L}$, a hemoglobin level of $101 \mathrm{~g} / \mathrm{L}$ with microcytic cells, and a platelet count of $306 \times 10^{9} / \mathrm{L}$. Her serum electrolytes and coagulation parameters were within normal limits. In the emergency department, the patient was empirically started on ceftriaxone and metronidazole for a presumed polymicrobial infection. She underwent a local incision and drainage, yielding a large amount of pus; however, when the superficial fascia was found to not be intact, the patient was transferred to the operating theatre for further exploration and debridement of all necrotic tissue. Clinically, only the superficial layers of tissue were involved, extending to (but not through) the deep fascia. Myonecrosis was absent. Clinically, a diagnosis of NF was entertained, and therapy with ceftriaxone and metronidazole was continued. Tissue was not submitted for histological evaluation; however, GAS was recovered from the specimens of pus submitted from aerobic and anaerobic culture and tissue from the left thigh.

The wound was managed using saline-moistened gauze dressings, and healing was achieved by secondary intention. The GAS isolate recovered from the patient's thigh was typed as M91, T type 5/27/44 and serum opacity factornegative.

\section{DISCUSSION}

Cases 1 and 2 presented within two days of each other to the same facility. The diagnosis of NF in case 1 was histopathologically based, while the diagnosis of case 2 was based on necrosis of the superficial fascia at the time of exploration. The patients from cases 1 and 2 did not know each other and did not have any other social, work or environmental interactions. $\mathrm{NF}$ is a potentially limb- and life-threatening infection, with mortality rates for those receiving inpatient care reported to be as high as $33 \%(3,16)$. As noted in our introduction, NF can be either mono- or polymicrobial in nature. Physical examination is unhelpful in differentiating between the two types, although a history of intra-abdominal surgery or a 'dirty' wound may serve as an indicator that a polymicrobial necrotizing infection might be occurring. Human bite injuries are often polymicrobial in nature, with the local flora of the mouth and skin, such as Clostridium, Streptococcus and Staphylococcus species, being the most common isolates (17). There are a large number of reports concerning NF and its etiology, and an equally large number of reports surrounding the epidemiology of human bite injuries. Despite all of these reports, there are remarkably few accounts of bite-related NF or STSS (Table 1). It has been reported that $2.3 \%$ of 15 - to 44 -year-old healthy individuals can asymptomatically carry GAS (18). Such carriage rates present a possible mechanism of transmission of GAS in this setting. 
TABLE 1

Reports of necrotizing fasciitis from human bites

\begin{tabular}{|c|c|c|c|c|c|c|c|c|c|c|}
\hline $\begin{array}{l}\text { Age } \\
\text { (years)/sex }\end{array}$ & $\begin{array}{l}\text { Location } \\
\text { of bite }\end{array}$ & $\begin{array}{l}\text { Mechanism } \\
\text { of injury }\end{array}$ & $\begin{array}{c}\text { Time to seek } \\
\text { medical } \\
\text { attention }\end{array}$ & Shock & $\begin{array}{l}\text { Method of } \\
\text { diagnosis }\end{array}$ & $\begin{array}{c}\text { Surgical } \\
\text { debridement }\end{array}$ & Therapy & $\begin{array}{l}\text { Recovered } \\
\text { microorganisms }\end{array}$ & $\begin{array}{l}\text { Patient } \\
\text { outcome }\end{array}$ & Reference \\
\hline 19/Man & Penis & $\begin{array}{l}\text { Minor trauma } \\
\text { to penis during } \\
\text { fellatio from } \\
\text { girlfriend }\end{array}$ & $72 \mathrm{~h}$ & No & Histopathology & Yes & $\begin{array}{l}\text { Ampicillin, } \\
\text { gentamicin } \\
\text { and } \\
\text { clindamycin }\end{array}$ & $\begin{array}{l}\text { Group A } \\
\text { streptococcus }\end{array}$ & Recovered & $\begin{array}{l}\text { Case } 1 \\
\text { from the } \\
\text { present } \\
\text { report }\end{array}$ \\
\hline 18/Woman & Thigh & $\begin{array}{l}\text { Bitten by } \\
\text { mother } \\
\text { during fight }\end{array}$ & $48 \mathrm{~h}$ & No & $\begin{array}{r}\text { Examination } \\
\text { at surgery }\end{array}$ & Yes & $\begin{array}{l}\text { Ceftriaxone and } \\
\text { metronidazole }\end{array}$ & $\begin{array}{l}\text { Group A } \\
\text { streptococcus }\end{array}$ & Recovered & $\begin{array}{l}\text { Case } 2 \\
\text { from the } \\
\text { present } \\
\text { report }\end{array}$ \\
\hline 42/Woman & Leg & $\begin{array}{l}\text { Bitten by an } \\
\text { unknown child } \\
\text { at a reception }\end{array}$ & $24 \mathrm{~h}$ & Yes & $\begin{array}{l}\text { Examination at } \\
\text { surgery and } \\
\text { histopathology }\end{array}$ & Yes & $\begin{array}{c}\text { Penicillin and } \\
\text { gentamicin }\end{array}$ & $\begin{array}{l}\text { Group A } \\
\text { streptococcus }\end{array}$ & $\begin{array}{l}\text { Died of } \\
\text { multiple organ } \\
\text { failure on } \\
\text { postoperative } \\
\text { day } 21\end{array}$ & n \\
\hline 74/Man & $\begin{array}{l}\text { Buccal } \\
\text { mucosa }\end{array}$ & $\begin{array}{l}\text { Inadvertently } \\
\text { bit himself } \\
\text { with ill-fitting } \\
\text { dentures }\end{array}$ & 5 days & No & $\begin{array}{r}\text { Examination } \\
\text { at surgery }\end{array}$ & Yes & $\begin{array}{l}\text { Sulbactam/ } \\
\text { cefoperazone }\end{array}$ & $\begin{array}{l}\text { Streptococcus } \\
\text { species, } \\
\text { Bacteroides } \\
\text { melaninogenicus, } \\
\text { Bacteroides oris, } \\
\text { Eubacterium } \\
\text { aerofaciens }\end{array}$ & Recovered & 13 \\
\hline 28/Man & Calf & $\begin{array}{l}\text { While dancing } \\
\text { on a nightclub } \\
\text { table, bitten by } \\
\text { an unknown } \\
\text { woman }\end{array}$ & $48 \mathrm{~h}$ & No & $\begin{array}{l}\text { Examination } \\
\text { at surgery and } \\
\text { histopathology }\end{array}$ & Yes & $\begin{array}{c}\text { Penicillin and } \\
\text { gentamicin }\end{array}$ & $\begin{array}{l}\text { Group A } \\
\text { streptococcus }\end{array}$ & Recovered & 12 \\
\hline $\begin{array}{l}\text { Unknown } \\
\text { age/Man }\end{array}$ & $\begin{array}{l}\text { Penis, } \\
\text { with groin } \\
\text { abscess }\end{array}$ & Not specified & 6 weeks & No & Not specified & Yes & $\begin{array}{l}\text { Vancomycin, } \\
\text { tobramycin } \\
\text { and clindamycin }\end{array}$ & $\begin{array}{l}\text { Group A } \\
\text { streptococcus }\end{array}$ & Recovered & 11 \\
\hline
\end{tabular}

A MEDLINE search spanning from 1966 to December 21, 2004, using the search terms "bite" and "necrotizing fasciitis" revealed only four reported cases in addition to the present cases. Also found was one case of STSS without NF arising from a human bite to the penile shaft as a result of oral sex (14). The paucity of search results could represent either an underreporting or a true rarity of these cases. From Table 1, it should be noted that for the cases where the time to seek medical attention was reported, the time ranged from $48 \mathrm{~h}$ to five days. GAS was recovered from five of the six reported cases; in the single case where GAS was not recovered, the patient had inadvertently bitten his own buccal mucosa, where Streptococcus species, Bacteroides melaninogenicus, Bacteroides oris and Eubacterium aerofaciens were recovered. With respect to this latter case, the true polymicrobial nature of the microorganisms recovered is comparable with the flora typically found in the mouth. The patients summarized in Table 1 had the diagnosis of NF established clinically at the time of surgery, histopathologically or using a combination of the two techniques. These patients received a variety of different antimicrobial regimens, which likely reflect the vintage of the cases reported, the background of the treating physicians, and local therapeutic practices. All but one of these summarized patients survived; however, the patient who died had a course complicated by shock, extensive skin and soft tissue debridement, and respiratory failure. Why this patient had such a complex course with a poor outcome is unclear, particularly when the other cases had seemingly more limited infections arising from what appear to be similar injuries. This may be related to the intrinsic virulence of the pathogens involved in the cases; unfortunately, data about strain types are unavailable for these cases.

In both previous reports (11-15) and the cases outlined in the present article, the source of the GAS is unclear; however, it is speculated that the organism originated from the throat/oropharynx of the person initiating the bite (assailant). In addition to GAS arising from the oropharynx of the assailant, there remains the possibility that GAS may have been on the skin of the person sustaining the bite injury (victim), with inoculation of the deep tissues occurring at the time of the bite. Unfortunately, the collection of GAS from the throat swabs of the assailant and victim was not attempted in previous reports (11-15) or in the present cases; these specimens would have provided definitive support for oral pharyngeal carriage of GAS serving as the source for the microorganism responsible for the victim's NF.

Cases 1 and 2 are important reminders that GAS can be inoculated through bite wounds, possibly from the oropharynx of the assailant or, alternatively, from the skin of the person who was bitten. Therefore, it is important to consider NF as a potential complication of a bite injury, a complication which 
may have catastrophic consequences (15). Bite wound infections are typically thought of as mixed with aerobes, particularly alpha-hemolytic streptococci, Staphylococcus aureus and anaerobes, which is what was observed in the patient who bit his own cheek $(13,17,19-21)$. In a recent report $(17), 14 \%$ of 50 patients presenting with infected human bites had GAS recovered from their wounds. GAS may indeed play a larger role than had previously been suspected. In a recent comprehensive clinical and bacteriological analysis of infected human bites in patients presenting to emergency departments (17), NF was not recorded among any of the 50 patients reviewed, which may represent underreporting or, alternatively, the true rarity of bite-related NF.

When initiating antibiotic treatment for suspected NF of GAS origin, it is important to ensure that penicillin - a highly effective agent against GAS - is included in the treatment regimen. Evidence for the concurrent use of clindamycin exists (primarily from animal models). However, human trials to validate the effect of antimicrobial agents in arresting protein synthesis with efficacy currently do not exist $(22,23)$. In addition to arresting toxin production by interfering with protein synthesis, the antibacterial spectrum of clindamycin targets

\section{REFERENCES}

1. Green RJ, Dafoe DC, Raffin TA. Necrotizing fasciitis. Chest 1996;110:219-29

2. DiNubile MJ, Lipsky BA. Complicated infections of skin and skin structures: When the infection is more than skin deep. J Antimicrob Chemother 2004;53(Suppl 2):ii37-50.

3. Bisno AL, Stevens DL. Streptococcal infections of skin and soft tissues. N Engl J Med 1996;334:240-5.

4. Bisno AL, Cockerill FR 3rd, Bermudez CT. The initial outpatientphysician encounter in group A streptococcal necrotizing fasciitis. Clin Infect Dis 2000;31:607-8.

5. Fontes RA Jr, Ogilvie CM, Miclau T. Necrotizing soft-tissue infections. J Am Acad Orthop Surg 2000;8:151-8.

6. Bisno AL, Brito MO, Collins CM. Molecular basis of group A streptococcal virulence. Lancet Infect Dis 2003;3:191-200.

7. Hackett SP, Stevens DL. Superantigens associated with staphylococcal and streptococcal toxic shock syndrome are potent inducers of tumor necrosis factor-beta synthesis. J Infect Dis 1993;168:232-5.

8. Kaul R, McGeer A, Norrby-Teglund A, et al. Intravenous immunoglobulin therapy for streptococcal toxic shock syndrome a comparative observational study. The Canadian Streptococcal Study Group. Clin Infect Dis 1999;28:800-7.

9. Lamothe F, D'Amico P, Ghosn P, Tremblay C, Braidy J, Patenaude JV. Clinical usefulness of intravenous human immunoglobulins in invasive group A Streptococcal infections: Case report and review. Clin Infect Dis 1995;21:1469-70.

10. Kaul R, McGeer A, Low DE, Green K, Schwartz B. Population-based surveillance for group A streptococcal necrotizing fasciitis: Clinical features, prognostic indicators, and microbiologic analysis of seventyseven cases. Ontario Group A Streptococcal Study. Am J Med 1997;103:18-24.

11. Wolf JS Jr, Gomez R, McAninch JW. Human bites to the penis. J Urol 1992;147:1265-7.
$S$ aureus and anaerobes. When considering injuries of the perineum, it may be prudent to also include antimicrobial agents effective against Gram-negative organisms and anaerobic species because it is clinically impossible to establish the microbiology of complicated skin and soft tissue infections (2). In case 2 , the treating physician was concerned about the potential for a polymicrobial infection; as a result, therapy was initiated. Although this therapy may not have been optimal for targeting GAS (as penicillin was absent), it was still sufficient to target the majority of Gram-positive and Gramnegative organisms and anaerobic species that may have potentially caused polymicrobial infection.

Cases 1 and 2, along with those found after reviewing published reports, serve as a reminder that NF may indeed occur after bites, with the source of the inoculated microorganism being either the oropharynx of the assailant or the skin of the victim itself. NF should therefore be considered in the differential diagnosis of bite-related infections.

ACKNOWLEDGEMENTS: The authors acknowledge the excellent secretarial skills of Carolyn Garlinski in the preparation of this manuscript.

12. Wienert P, Heiss J, Rinecker H, Sing A. A human bite. Lancet 1999;354:572.

13. Yamaoka M, Furusawa K, Kiga M, Iguchi K, Hirose I. Necrotizing buccal and cervical fasciitis. J Craniomaxillofac Surg 1990;18:223-4.

14. Behar DM, Edelshtein S, Ben-Ami H, Mansano R, Edoute Y. Human bite on penile shaft from oral sex as a portal of entry for streptococcal toxic shock syndrome. Isr Med Assoc J 2000;2:945-7.

15. Danino AM, Malka G. A lethal necrotizing fasciitis after human bite. Plast Reconstr Surg 2004;113:2234-5.

16. Cunningham JD, Silver L, Rudikoff D. Necrotizing fasciitis: A plea for early diagnosis and treatment. Mt Sinai J Med 2001;68:253-61.

17. Talan DA, Abrahamian FM, Moran GJ, Citron DM, Tan JO, Goldstein EJ; Emergency Medicine Human Bite Infection Study Group. Clinical presentation and bacteriologic analysis of infected human bites in patients presenting to emergency departments. Clin Infect Dis 2003;37:1481-9.

18. Hoffmann $\mathrm{S}$. The throat carrier rate of group $\mathrm{A}$ and other beta hemolytic streptococci among patients in general practice. Acta Pathol Microbiol Immunol Scand 1985;93:347-51.

19. Goldstein EJ, Citron DM, Wield B, et al. Bacteriology of human and animal bite wounds. J Clin Microbiol 1978;8:667-72.

20. Goldstein EJ, Miller TA, Citron DM, Finegold SM. Infections following clenched-fist injury: A new perspective. J Hand Surg 1978;3:455-7.

21. Brook I. Microbiology of human and animal bite wounds in children. Pediatr Infect Dis J 1987;6:29-32.

22. Zimbelman J, Palmer A, Todd J. Improved outcome of clindamycin compared with beta-lactam antibiotic treatment for invasive Streptococcus pyogenes infection. Pediatr Infect Dis J 1999;18:1096-100.

23. Coyle EA; Society of Infectious Diseases Pharmacists. Targeting bacterial virulence: The role of protein synthesis inhibitors in severe infections. Insights from the Society of Infectious Diseases Pharmacists. Pharmacotherapy 2003;23:638-42. 


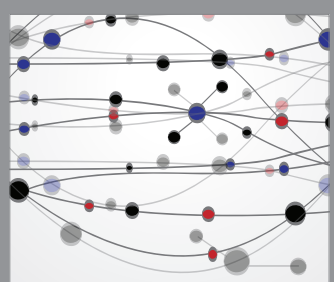

The Scientific World Journal
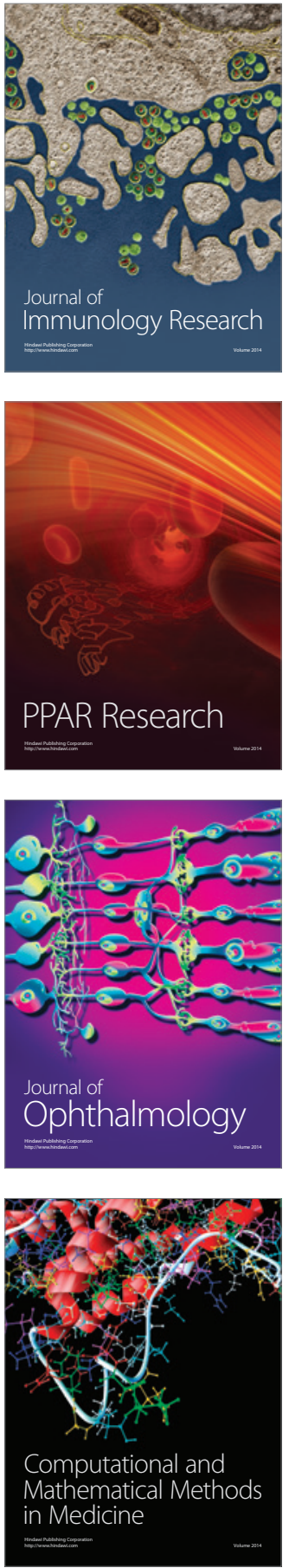

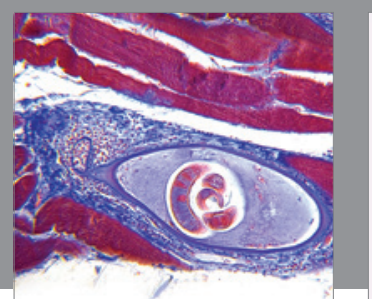

Gastroenterology Research and Practice

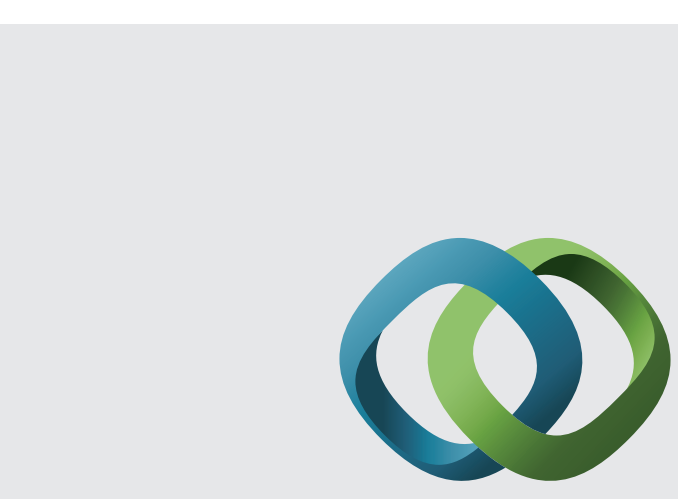

\section{Hindawi}

Submit your manuscripts at

http://www.hindawi.com
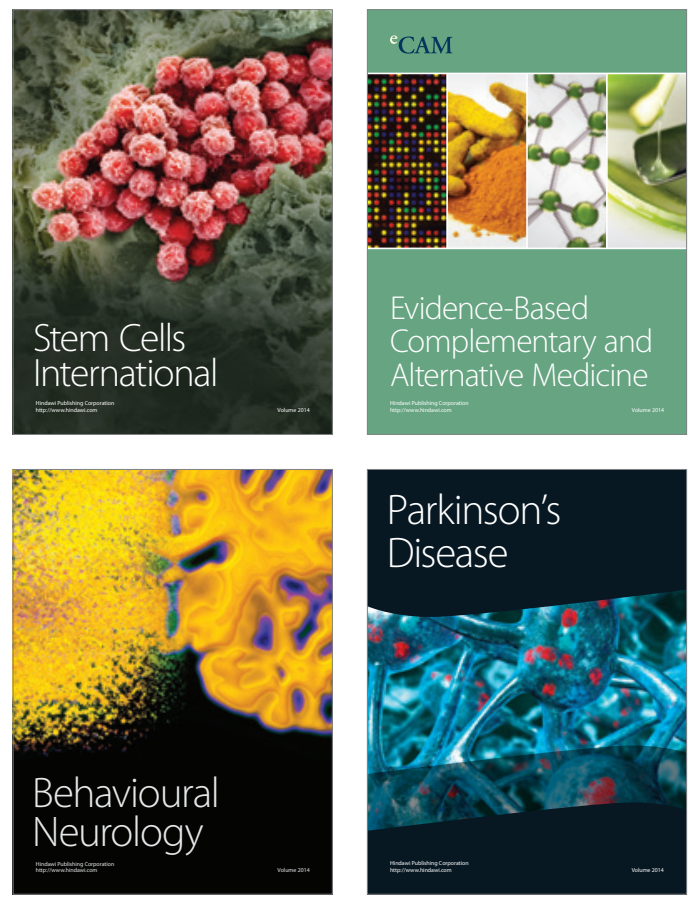
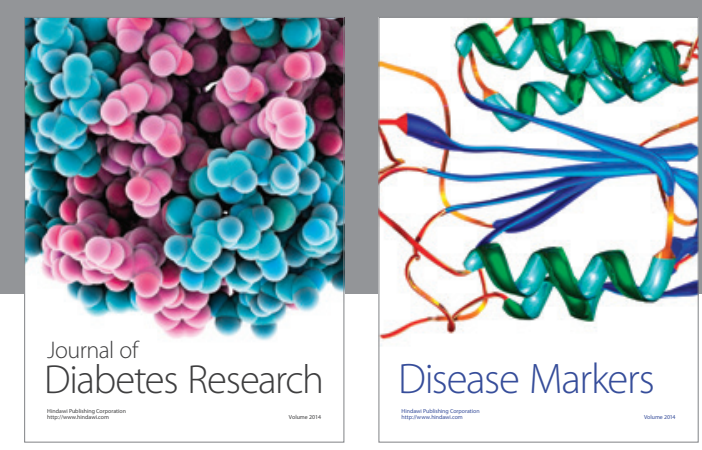

Disease Markers
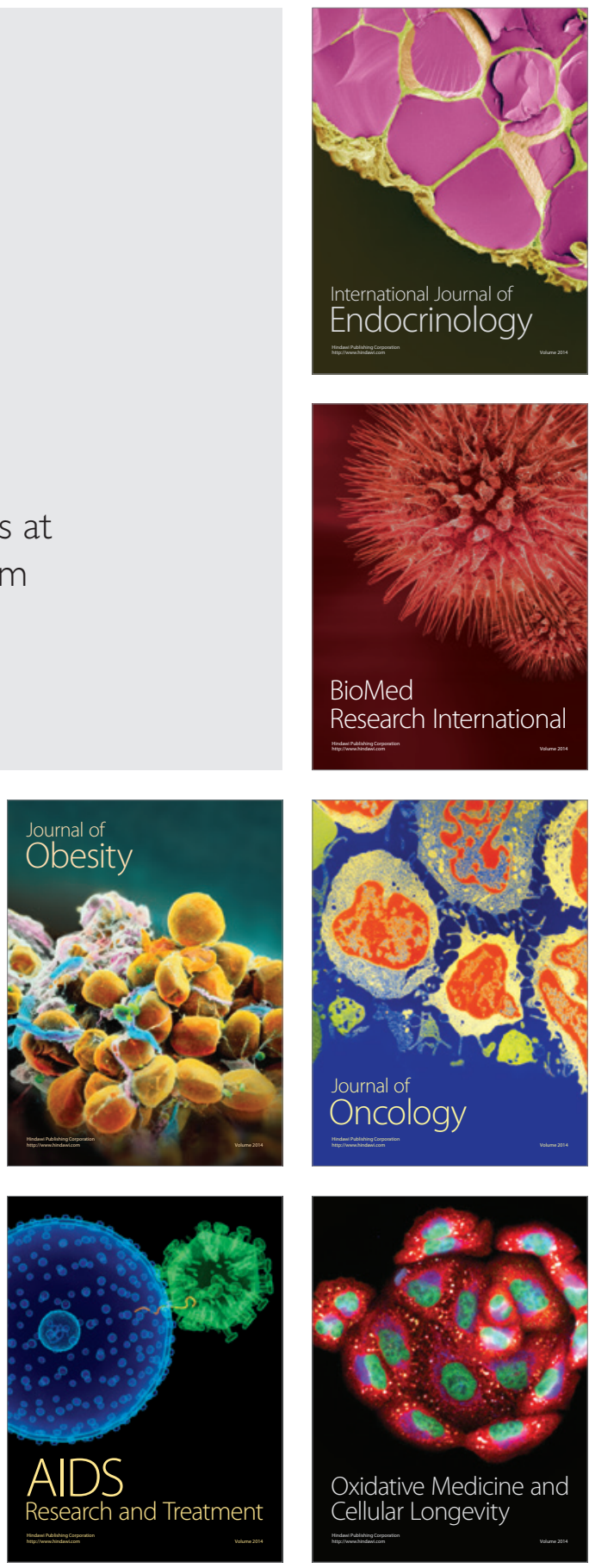